Volume 6 Nomor 1, Februari 2021, halaman 109 - 124.

\title{
Pengaruh Kemampuan Metakognisi Terhadap Hasil Belajar Matematika Siswa SMA
}

\section{Effect of Metacognition Skills on Mathematics Learning Outcomes of High School Students}

\author{
Nirfayanti ${ }^{1}$, Erna $S^{2}$ \\ ${ }^{1}$ Universitas Muslim Maros, Jln.Dr.Ratulangi No.62 Maros, nirfa@umma.ac.id \\ ${ }^{2}$ Universitas Muslim Maros, Jln.Dr.Ratulangi No.62 Maros, \\ ernawati152708@gmail.com
}

\begin{abstract}
ABSTRAK
Penelitian ini bertujuan untuk mengetahui dan mendeskripsikan pengaruh kemampuan metakognisi terhadap hasil belajar matematika siswa kelas X SMA Negeri 3 Maros. Jenis penelitian yang digunakan merupakan penelitian ex-post facto. Populasi dalam penelitian tersebut adalah siswa kelas X SMA Negeri 3 Maros yang berjumlah 300 siswa, terdiri dari 6 kelas MIPA dan 3 kelas IPS. Sedangkan sampel yang akan diteliti adalah 100 siswa dengan teknik pengambilan sampel adalah Simple Random Sampling. Instrumen yang digunakan dalam penelitian ini adalah angket kemampuan metakognisi dan tes hasil belajar matematika. Teknik analisis yang digunakan adalah statistik deskriptif dan statistik inferensial dengan pengujian hipotesis penelitian menggunakan analisis Regresi Linier Sederhana. Berdasarkan hasil analisis data menggunakan statistik deskriptif, untuk pengetahuan metakognisi diperoleh nilai rata-rata 27,6 berada pada kategori sedang dari 100 sampel diperoleh nilai terendah 19,51 dan nilai tertinggi 33,28. Sedangkan untuk pengalaman/regulasi metakognisi diperoleh rata-rata 47,8 berada pada kategori tinggi dari 100 sampel diperoleh nilai terendah 37,95 dan nilai tertinggi 55,55 dan untuk hasil belajar matematika diperoleh nilai rata-rata 76 berada pada kategori sedang dari 100 sampel diperoleh nilai terendah 56 dan nilai tertinggi 92 . Hal ini juga dapat dilihat dari persamaan regresi dengan besar konstribusi $5,8 \%$. Sehingga dapat disimpulkan bahwa kemampuan metakognisi berpengaruh signifikan terhadap hasil belajar matematika siswa.
\end{abstract}

Kata Kunci : Pengetahuan Metakognisi, Regulasi Metakognisi, Hasil Belajar Matematika

\begin{abstract}
This study aims to determine and describe the effect of metacognition abilities on mathematics learning outcomes of class X SMA Negeri 3 Maros. This type of research is ex-post facto research. The population in this study were 300 students of class X SMA Negeri 3 Maros, consisting of 6 MIPA classes and 3 social studies classes. While the sample to be studied was 100 students with the sampling technique is Simple Random Sampling. The instruments used in this study were a metacognition ability questionnaire and a mathematics learning outcome test. The analysis technique used is descriptive statistics and inferential statistics by testing the research hypothesis using simple linear regression analysis. Based on the results of data analysis using descriptive statistics, for metacognition knowledge an average value of 27,6 is in the medium category of 100 samples, the lowest value is 19,51 and the highest value is 33,28 . Whereas for the experience / regulation of metacognition, it was obtained an average of 47,8 was in the high category of 100 samples, the lowest score was 37,95 and the highest score was 55,55 and for mathematics learning outcomes it was obtained an average value of 76 in the medium category of 100 samples. obtained the lowest score of 56 and the highest score of 92. This can also be seen from the regression equation with a contribution of $5,8 \%$. So it can be concluded that metacognition ability has a significant effect on students' mathematics learning outcomes.
\end{abstract}

Keyword(s): Knowledge of Metacognition, Regulation of Metacognition, Learning Outcomes Mathematics 


\section{How to Cite: Nirfayanti., S, Erna. (2021). Pengaruh Kemampuan Metakognisi Terhadap Hasil Belajar Matematika Siswa SMA. Mathline: Jurnal Matematika dan Pendidikan Matematika, Vol. 6 No. 1, 109 - 124. \\ DOI: $\underline{\text { https://doi.org/10.31943/mathline.v6i1.178 }}$}

\section{PENDAHULUAN}

Matematika merupakan salah satu ilmu dasar dalam membentuk sikap dan menumbuh kembangkan kemampuan berpikir logis, sistematis serta kritis dalam diri siswa. Peranan matematika cukup besar dalam mengembangkan IPTEKS yaitu salah satunya sarana dalam mengembangkan kemampuan berpikir seseorang. Namun, berbeda dengan kenyataan yang ada, sebagian besar siswa beranggapan bahwa mata pelajaran matematika merupakan pelajaran yang sulit mengakibatkan siswa kurang termotivasi dalam belajar matematika sehingga hasil belajar siswa rendah.

Dalam riset yang dilakukan oleh Ismail dkk (2019) dan Syamsuriyawati \& Setyawan (2019) bahwa guru dalam melakukan proses pembelajaran masih bersifat konvensional atau pembelajaran hanya berpusat pada guru sehingga ada rasa jenuh yang timbul pada peserta didik. Oleh karena itu, peserta didik tidak berminat dalam mengikuti pembelajaran dan ketidakpahaman peserta didik terhadap konsep matematika itu sendiri sehingga akan berpengaruh pada hasil belajarnya.

Hal telah dilakukan berulang-ulang dari suatu asesmen dan pengenalan dinamakan dengan hasil belajar. Hasil belajar tersebut dijadikan patokan atau kriteria dalam mencapai suatu tujuan pendidikan. Standar nasional pendidikan mengungkapkan bahwa penilaian hasil belajar oleh pendidik dilakukan secara berkesinambungan untuk memantau proses, kemajuan, dan perbaikan hasil dalam bentuk penilaian harian, penilaian tengah semester, dan penilaian kenaikan kelas (Nasrodin, 2018: 71). Hasil belajar matematis merupakan kemampuan atau hasil pekerjaaan siswa yang dapat diamati melalui perubahan pengetahuan pada bidang matematika (Ismunandar \& Nurafifah, 2018).

Menurut Sudjana (2010 : 22) peserta didik yang memiliki kemampuan setelah mendapatkan pengalaman belajarnya disebut dengan hasil belajar. Hasil belajar memiliki peranan penting pada proses pembelajaran. Informasi evaluasi kemajuan hasil belajar peserta didik diberikan pada guru sebagai upaya mencapai tujuan pembelajaran melalui aktivitas belajarnya. Selanjutnya berdasarkan informasi tersebut, aktivitas-aktivitas peserta didik disusun dan dibina oleh guru lebih lanjut, baik seluruh kelas maupun perorangan. Hasil akhir dari proses akhir belajar mengajar sebagai perwujudan segala upaya yang telah 
dilakukan selama proses berlangsung lebih sering dikaitkan dengan pengelolaan kelas dan nilai siswa setelah evaluasi diberikan yang selanjutnya dikenal sebagai hasil belajar.

Dua Faktor yang mempengaruhi hasil belajar yaitu faktor internal dan faktor eksternal. Faktor internal meliputi intelegensi, kecemasan, motivasi, kebiasaan, minat, dan kemampuan-kemampuan kognitif seperti kemampuan persepsi, ingatan, dan sebagainya. Sedangkan faktor eksternal meliputi keadaan sosial ekonomi, lingkungan sekolah, lingkungan masyarakat, lingkungan keluarga, dan sebagainya.

Dari hasil wawancara dengan guru matematika kelas X di SMA Negeri 3 Maros diperoleh informasi bahwa hasil ulangan matematika siswa kelas $\mathrm{X}$ tidak mencapai nilai standar Kriteria Ketuntasan Maksimum (KKM) yakni 75. Padahal sebelum ulangan semester dilakukan prasemester yang soalnya tidak jauh berbeda dari soal yang diberikan saat prasemester. Hanya saja yang berbeda adalah jumlah soalnya. Namun, tetap saja nilai ulangan siswa berada di bawah standar. Dari hasil pengamatan juga bahwa penyelesaian soal-soal non rutin yang dilakukan siswa sangat lemah khususnya dalam pemecahan masalah yang membutuhkan penalaran matematis. Sehingga, hal ini berdampak pada rendahnya hasil belajar matematika siswa. Salah satu penyebab matematika dianggap sulit oleh siswa adalah pembelajarannya tidak diimplementasikan dalam kehidupan sehari-hari, hanya berupa konsep-konsep matematika saja. Hal inilah yang mengakibatkan matematika sulit diterapkan dalam kehidupan nyata dan dipandang sebagai ilmu yang abstrak sehingga sebagian besar siswa tidak tertarik dengan matematika. Namun, salah satu tujuan pembelajaran matematika adalah mampu menyelesaikan masalah, maka siswa haruslah belajar matematika agar dapat membantu dirinya dalam memecahkan persoalan baik dalam pelajaran lain maupun dalam kehidupan sehari-hari.

Metakognisi dikenal sebagai proses menyadari kemampuan dan berpikir siswa dalam memecahkan masalah. Kemampuan metakognisi merupakan kesadaran seseorang yang memuat proses kognitifnya atau proses pengaturan diri seseorang dalam belajar sehingga cara belajar diketahui oleh individu tersebut, waktu yang tepat untuk belajar, belajar menggunakan strategi yang cocok sehingga setiap hal yang dilakukan dapat terkontrol secara optimal. Kemampuan metakognisi memungkinkan siswa mampu mengelola kecakapan kognitif dan mampu melihat kelemahan siswa itu sendiri sehingga siswa dapat melakukan perbaikan pada tindakan-tindakan berikutnya.

Pada dasarnya, setiap individu memiliki kemampuan metakognisi. Pada saat-saat tertentu, kemampuan seseorang dalam hal belajar direfleksikan dan dipikirkan serta dilakukan strategi-strategi untuk diselesaikan tugasnya atau masalah yang dihadapi dalam 
proses belajarnya. Akan tetapi, kegiatan metakognisi yang dilakukan tersebut tidak disadari oleh individu. Individu memiliki tingkat kemampuan metakognisi yang berbeda-beda tergantung dari aktivitas belajar yang dilakukannya (Novitasari, 2015: 4).

Seorang peserta didik yang baik akan mengawali aktivitas belajarnya dengan merencanakan apa yang akan dilakukannya ketika belajar, dan akan memutuskan menguasai apa yang telah dipelajarinya jadi jika dirasakan siswa bahwa suatu pelajaran atau pembahasan pelajaran tidak mengerti oleh siswa, maka siswa akan lebih aktif untuk mempelajarinya. Seperti membuat perencanaan apa yang akan dipelajari, melakukan pemantauan terhadap hasil belajar, mengevaluasi hasil belajar yang diperoleh, mengulang, mengorganisasi belajarnya, dan berusaha untuk mencapai hasil belajar yang optimal. Berdasarkan penelitian Wati dkk (2017) dan Lusiana (2017) perlu mendapat perhatian dan diidentifikasi sejauh mana penugasan peserta didik terhadap materi dilakukan, serta mengetahui mengapa kesalahan tersebut dilakukan (Hidayat et al., 2013; Widodo, 2013; Siswandi, Sujadi, \& Riyadi, 2016). Namun, kenyataannya siswa kelas X SMA Negeri 3 Maros belum menyadari proses pemecahan masalah tersebut dan jarang diasah penalaran siswa. Oleh karena itu, perlu mendapat perhatian khusus yang terkait dengan pembelajaran matematika dalam hal kemampuan metakognisi siswa sehingga nantinya siswa dapat mengatur dan mengontrol proses-proses kognitifnya dalam belajar dan berpikir serta berdampak pada hasil belajarnya. Berdasarkan penjelasan tersebut, peneliti tertarik untuk melakukan riset yang berjudul "Pengaruh Kemampuan Metakognisi terhadap Hasil Belajar Matematika Siswa SMA”.

\section{METODE PENELITIAN}

Penelitian Ex-Post Facto, peneliti gunakan sebagai metode riset, yaitu riset tentang variabel yang kejadiannya sudah ada sebelum riset dilaksanakan (Arikunto, 2010: 17). Penelitian ini bertujuan untuk mengetahui pengaruh variabel bebas terhadap variabel terikat. Desain yang diterapkan adalah menghubungkan kedua variabel bebas terhadap variabel terikat.

Penelitian ini dilaksanakan di SMA Negeri 3 Maros. Adapun waktu penelitian dilaksanakan pada semester genap tahun pelajaran 2019/2020 tepatnya pada bulan Mei sampai dengan bulan Juni 2020.

Populasi penelitian ini adalah semua siswa kelas X SMA Negeri 3 Maros yang berjumlah 300 siswa terdiri dari 6 kelas MIPA dan 3 kelas IPS pada tahun ajaran 2019/2020. Tingkatan sekolah yang akan menjadi partisipan dalam penelitian ini adalah 
siswa kelas X MIPA SMA Negeri 3 Maros dengan jumlah partisipan sebanyak 100 siswa. Teknik Simple Random Sampling diambil peneliti dalam pemilihan sampel. Pengambilan sampel dilakukan secara acak, yaitu melakukan pengambilan anggota sampel dari populasi tanpa memperhatikan strata yang ada dalam populasi itu.

Teknik pengumpulan data dilakukan dengan menggunakan angket dalam bentuk skala perilaku yang mengharuskan responden memilih satu dari empat pilihan jawaban yang telah disediakan dengan memberikan tanda check list $(\sqrt{ })$ pada pilihan yang sesuai dengan keadaan dirinya. Penelitian ini menggunakan skala likert yang diberikan kepada responden, untuk mengetahui kemampuan metakognisi yang dimiliki siswa yang berjumlah 25 pernyataan dan tes bentuk essay digunakan untuk mengukur hasil belajar matematika siswa sebanyak 5 soal.

Teknik analisis data yang digunakan adalah statistik deskriptif dan statistik inferensial. Data kemampuan metakognisi dan hasil belajar matematika dijelaskan melalui statistik deskriptif. Sedangkan analisis regresi linear sederhana digunakan untuk mengetahui pengaruh kemampuan metakognisi terhadap hasil belajar matematika melalui SPSS versi 25.

\section{HASIL DAN PEMBAHASAN}

\section{Analisis Statistik Deskriptif}

Analisis statistik deskriptif digunakan untuk mendeskripsikan secara umum variabel penelitian yakni kemampuan metakognisi dan hasil belajar siswa melalui data yang terkumpul. Tabel 1 dibawah ini menunjukkan hasil perhitungan dan pengujian yang dilakukan dengan bantuan aplikasi SPSS for windows serta analisis dan interpretasinya:

Tabel 1. Deskripsi Statistics Kemampuan Metakognisi dan Hasil Belajar

\begin{tabular}{lrrr}
\hline \multirow{2}{*}{ Statistik } & \multicolumn{2}{c}{ Kemampuan Metakognisi } & Hasil Belajar \\
\cline { 2 - 3 } & $\begin{array}{c}\text { Pengetahuan } \\
\text { Metakognisi }\end{array}$ & $\begin{array}{c}\text { Pengalaman/Regulasi } \\
\text { Metakognisi }\end{array}$ & 100 \\
\hline $\mathrm{N}$ & 100 & 100 & 76.0400 \\
Mean & 27.5208 & 3.14373 & 8.85794 \\
Std. Deviation & 2.67897 & 9.883 & 78.463 \\
Variance & 7.177 & 17.61 & 36.00 \\
Range & 13.51 & 37.95 & 56.00 \\
Minimum & 19.51 & 55.55 & 92.00 \\
Maximum & 33.28 & &
\end{tabular}


Disamping itu, pengkategorian data kemampuan metakognisi dan hasil belajar matematika siswa kelas X MIPA SMA Negeri 3 Maros dapat dilihat pada tabel 2 berikut.

Tabel 2. Kriteria Pengkategorian Data Kemampuan Metakognisi dan Hasil Belajar

\begin{tabular}{cc}
\hline Kategori & Batas Kategori \\
\hline Rendah & $x<(\mu-1,0 \sigma)$ \\
Sedang & $(\mu-1,0 \sigma) \leq x<(\mu+1,0 \sigma)$ \\
Tinggi & $(\mu+1,0 \sigma) \leq x$ \\
\hline
\end{tabular}

Sumber: Saifuddin Azwar (Saputri, 2018: 72)

Berdasarkan tabel 1 tersebut menunjukkan bahwa skor rata-rata kemampuan metakognisi matematika siswa yang terdiri dari pengetahuan dan pengalaman metakognisi siswa kelas X MIPA SMA Negeri 3 Maros masing-masing adalah 27,5208 dan 47,7549; masing-masing varians 7,177 dan 9,883, dan masing-masing standar deviasi 2,67897 dan 3,14373. Hasil dari tabel 1 tersebut menunjukkan bahwa hasil kemampuan metakognisi siswa kelas X MIPA SMA Negeri 3 Maros yang sumbangsihnya besar (dominan) adalah pengalaman metakognisi karena pada pengalaman metakognisi memiliki interpretasi paling besar dibandingkan dengan pengetahuan metakognisi. Sedangkan skor rerata hasil belajar matematika siswa kelas X MIPA SMA Negeri 3 Maros adalah 76,0400; varians 78,463, dan standar deviasi 8,85794. Berdasarkan deskripsi tersebut menunjukkan bahwa kemampuan metakognisi matematika siswa kelas X MIPA SMA Negeri 3 Maros memiliki pemusatan data pada 27,5208 dan 47,7549 dan penyebaran data dengan variasi sebesar 7,177 dan 9,883 serta standar deviasi sebesar 2,67897 dan 3,14373. Sedangkan hasil belajar matematika siswa mempunyai pemusatan data pada 76,0400 dan penyebaran data dengan variasi sebesar 78,463 dan standar deviasi sebesar 8,85794.

Dengan demikian, jika nilai rata-rata kemampuan metakognisi siswa dan hasil belajar dimasukkan ke dalam kriteria pengkategorian pada tabel 2 maka dapat disimpulkan bahwa skor rata-rata pengetahuan metakognisi yaitu 27,5208 dikategorikan sedang dan skor rata-rata pengalaman metakognisi yaitu 47,7549 berada pada kategori tinggi serta skor rata-rata hasil belajar matematika siswa pada penelitian ini yaitu 76,0400 termasuk pada kategori sedang

\section{Analisis Statistik Inferensial}

\section{a. Uji Normalitas}

Pada penelitian ini untuk mengetahui normal atau tidaknya data penelitian maka dilakukan uji normalitas. Pada penelitian ini digunakan uji Kolmogorov-Smirnov pada 
tingkat signifikansi 5\%. Distribusi data penelitian dikatakan berdistribusi normal jika hasil analisis diperoleh nilai signifikansi $\alpha \geq 0,05$, sedangkan jika nilai nilai signifikansi $\alpha<0,05$ menunjukkan data tidak berdistribusi normal.

Tabel 3. Hasil Analisis Uji Normalitas

\begin{tabular}{l|lr}
\hline & & Unstandardized Residual \\
\hline $\mathrm{N}$ & Mean & 100 \\
Normal Parameters & Std. Deviation & .0000000 \\
Most Extreme & Absolute & 8.59787804 \\
Differences & Positive & .045 \\
& Negative & .045 \\
Test Statistic & & -.042 \\
Asymp. Sig. (2-tailed) & .045 \\
\end{tabular}

Berdasarkan uji normalitas dengan Kolmogorof-Smirnov Test maka, diperoleh nilai

Test Statistic sebesar 0,045 dan Asymp. Sig. sebesar 0,200 sehingga nilai Asymp. Sig. $\geq$ 0,05. Dengan demikian, data yang diteliti berasal dari sampel yang berdistribusi normal.

\section{b. Uji Linearitas}

Uji linearitas bertujuan untuk mengetahui apakah dua pengujian linearitas ditentukan berdasarkan ANOVA tabel menggunakan SPSS 25 dengan memperhatikan hasil uji $\mathrm{F}$ untuk baris deviation from linearity. Dalam hal ini kaidah yang digunakan adalah jika F signifikan, maka hubungan kedua variabel linear. Uji linearitas dilakukan melalui uji $\mathrm{F}$ menggunakan taraf signifikansi $\alpha=0,05$, maka kriteria pengambilan keputusannya yaitu jika nilai signifikansinya $\geq 0,05$ maka $\mathrm{H}_{0}$ diterima, sedangkan jika nilai signifikansinya $<0,05$ maka $\mathrm{H}_{0}$ ditolak.Adapun hasil uji linearitas dapat dilihat pada tabel 4 berikut:

Tabel 4. Hasil Analisis Uji Linearitas

\begin{tabular}{|c|c|c|c|c|c|c|c|}
\hline & & & \multicolumn{5}{|c|}{ Mean } \\
\hline & & & Sum of Squares & df & Square & $\mathbf{F}$ & Sig. \\
\hline Hasil Belajar* & Between & (Combined) & 7667.840 & 96 & 79.873 & 2.396 & .259 \\
\hline Kemampuan & Groups & Linearity & 449.413 & 1 & 449.413 & 13.482 & .035 \\
\hline \multirow[t]{3}{*}{ Metakognisi } & & Deviation from Linearity & 7218.427 & 95 & 75.983 & 2.280 & .274 \\
\hline & Within G & & 100.000 & 3 & 33.333 & & \\
\hline & Total & & 7767.840 & 99 & & & \\
\hline
\end{tabular}

Berdasarkan tabel 4 diketahui bahwa nilai signifikansi sebesar 0,274 karena nilai sig. 0,274 $\geq 0,05$ maka $\mathrm{H}_{0}$ diterima, sehingga dapat disimpulkan bahwa kemampuan metakognisi terhadap hasil belajar bersifat linear. 


\section{c. Uji Hipotesis}

Setelah dilakukan uji prasyarat analisis data, diketahui bahwa data nilai kemampuan metakognisi dan hasil belajar pada penelitian ini berdistribusi normal dan linear, sehingga pengujian data dapat dilanjutkan pada analisis data selanjutnya, yaitu pengujian hipotesis dengan menggunakan analisis regresi linear sederhana pada taraf signifikan $\alpha(0,05)$ atau menggunakan uji t-test. Pengujian hipotesis ini dilakukan untuk mengetahui pengaruh kemampuan metakognisi terhadap hasil belajar matematika siswa kelas X SMA Negeri 3 Maros.

Untuk mengetahui koefisien regresi tersebut berpengaruh atau tidak (dalam artian variabel kemampuan metakognisi $(\mathrm{X})$ berpengaruh terhadap variabel hasil belajar (Y) dapat kita lakukan uji hipotesis dengan membandingkan nilai signifikan (Sig) dengan probabilitas 0,05 .

$\mathrm{H}_{\mathrm{o}}$ : Tidak terdapat pengaruh yang signifikan antara kemampuan metakognisi terhadap hasil belajar

matematika siswa kelas X SMA Negeri 3 Maros

$\mathrm{H}_{\mathrm{a}}$ : Terdapat pengaruh yang signifikan antara kemampuan metakognisi terhadap hasil belajar

matematika siswa kelas X SMA Negeri 3 Maros

Ketentuan:

1. Jika nilai signifikansi (Sig)>0,05, mengandung arti bahwa ada pengaruh kemampuan metakognisi terhadap hasil belajar matematika siswa kelas X SMA Negeri 3 Maros.

2. Sebaliknya, jika nilai signifikansi $($ Sig) $<0,05$, mengandung arti bahwa tidak ada pengaruh kemampuan metakognisi terhadap hasil belajar matematika siswa kelas $\mathrm{X}$ SMA Negeri 3 Maros.

Tabel 5. Hasil Analisis Signifikansi Kemampuan Metakognisi Terhadap Hasil Belajar

\begin{tabular}{|c|c|c|c|c|c|c|}
\hline \multirow[t]{2}{*}{ Mo } & & \multicolumn{2}{|c|}{$\begin{array}{c}\text { Unstandardized } \\
\text { Coefficients }\end{array}$} & \multirow{2}{*}{$\begin{array}{c}\text { Standardized } \\
\text { Coefficients } \\
\text { Beta }\end{array}$} & \multirow[t]{2}{*}{$\mathbf{t}$} & \multirow[t]{2}{*}{ Sig. } \\
\hline & & B & $\begin{array}{l}\text { Std. } \\
\text { Error }\end{array}$ & & & \\
\hline \multirow[t]{2}{*}{1} & (Constant) & 30.088 & 18.752 & & $\begin{array}{r}1.60 \\
5\end{array}$ & .112 \\
\hline & $\begin{array}{l}\text { Kemampuan } \\
\text { Metakognisi }\end{array}$ & .611 & .249 & .241 & $\begin{array}{r}2.45 \\
3\end{array}$ & .016 \\
\hline
\end{tabular}

Berdasarkan tabel 5 diketahui nilai signifikansi (Sig) sebesar $0,016<0,05$, yang

berarti bahwa kemampuan metakognisi berpengaruh positif terhadap hasil belajar 
matematika siswa. Adapun persamaan regresi untuk kedua variabel tersebut adalah $\mathrm{Y}=$ $30,088+0,611 \mathrm{X}$, dari persamaan tersebut koefisien regresinya sebesar 0,611 yang artinya bahwa setiap penambahan (peningkatan) kemampuan metakognisi siswa akan mempengaruhi hasil belajar matematika sebesar 0,611.

Hasil perhitungan uji statistik yang dilakukan dengan menggunakan software SPSS 25 diperoleh nilai signifikan 0,16 yang artinya hal tersebut menunjukkan adanya hubungan linier antara kemampuan metakognisi dan hasil belajar. Berdasarkan hasil analisis diketahui nilai $\mathrm{R}$ yaitu 0,241 dan R Square sebesar 0,058, nilai ini mengandung arti bahwa pengaruh kemampuan metakognisi $(\mathrm{X})$ terhadap kinerja yang dihitung dengan koefisien korelasi adalah 0,241. Sedangkan konstribusi atau sumbangan secara simultan variabel kemampuan metakognisi terhadap hasil belajar adalah 0,058 atau 5,8\%. Hal ini menunjukkan bahwa 94,2\% hasil belajar siswa dipengaruhi oleh variabel lain yang tidak diteliti dalam penelitian ini. Hasil perhitungan statistik di atas dapat menunjukkan bahwa terdapat pengaruh antara kemampuan metakognisi terhadap hasil belajar matematika siswa kelas X MIPA SMA Negeri 3 Maros.

\section{Pembahasan}

Metakognisi merupakan proses kognitif yang terkait pengetahuan dan kesadaran, atau pengetahuan tentang pikiran dan cara kerjanya. Metakognisi adalah suatu proses mengungkapkan rasa ingin tahu dalam merenungkan proses kognitif kita sendiri. Metakognisi ini memiliki arti yang sangat penting, karena pengetahuan tersebut ditata dan diseleksi agar dapat meningkatkan kemampuan kognitifnya pada masa yang akan dating (Nurani, 2017: 34).

Kemampuan metakognisi berkaitan dengan kesadaran seseorang tentang proses kognitifnya. Oleh karena itu, kemampuan metakognisi berperan penting dalam pembelajaran matematika, khususnya dalam mengatur dan mengontrol aktivitas kognitif siswa dalam belajar dan berpikir sehingga belajar dan berpikir yang dilakukan siswa menjadi lebih efektif dan efisien. Sehingga dengan diketahuinya jenis kemampuan yang berhubungan dalam proses belajar matematika siswa, maka peningkatan hasil belajar siswa akan lebih mudah diupayakan yaitu dengan mengembangkan kemampuan tersebut (Nurmalasari dkk., 2015: 140).

Metakognisi merupakan suatu kata tentang apa yang dia ketahui sebagai individu yang belajar dan bagaimana dia mengontrol serta menyesuaikan perilakunya. Oleh karena itu, Keberhasilan seorang siswa dalam menyelesaikan soal matematika dapat bergantung 
pada kesadarannya tentang apa yang ia ketahui dan bagaimana ia menerapkannya atau bermetakognisi (Kamid, 2013: 64). Semakin baik kemampuan metakognisi maka semakin baik pula hasil belajar matematika siswa tersebut. Sebaliknya, semakin rendah kemampuan metakognisi yang dimiliki siswa maka kemungkinan semakin rendah pula hasil belajar yang diperoleh siswa tersebut (Nurani, 2017: 101).

Hal penelitian ini relevan dengan hasil penelitian terdahulu yang dilakukan oleh Nurmalasari dkk (2015: 147) bahwa 28,9\% hasil belajar matematika siswa dipengaruhi oleh kemampuan metakognisi dan 71,1\% dipengaruhi oleh faktor lain. Sedangkan Fajriani \& Nurdahniar (2016: 289) mengemukakan bahwa 33,1\% hasil belajar matematika siswa dipengaruhi oleh kemampuan metakognisi dan sisanya dipengaruhi oleh faktor lain.

Adapun hasil penelitian ini menunjukkan bahwa 5,8\% hasil belajar matematika siswa dipengaruhi oleh kemampuan metakognisi dengan nilai sig. 0,016 < $\alpha$. Dengan demikian, maka dapat disimpulkan bahwa kemampuan metakognisi mempunyai pengaruh positif terhadap hasil belajar matematika siswa kelas X SMA Negeri 3 Maros walaupun persentasenya sedikit. Hal tersebut menunjukkan bahwa ada faktor lain yang berpengaruh terhadap hasil belajar matematika siswa selain kemampuan metakognisi. Menurut Thayeb (2017) penerapan model pembelajaran metakognitif berbasis masalah terbuka dapat meningkatkan keterampilan pemecahan masalah matematika siswa dikarenakan pembelajarannya lebih menekankan pada aktivitas siswa dalam mengarahkan kesadaran dan pengaturan berpikirnya (metakognisi).

Dalam penelitian ini, ada 2 aspek kemampuan metakognisi yang diukur yaitu pengetahuan metakognisi dan pengalaman/regulasi metakognisi. Anderson \& Kathwohl (Syaiful, 2011) menyatakan bahwa "pengetahuan metakognisi adalah pengetahuan tentang kognisi, secara umum sama dengan kesadaran dan pengetahuan tentang kognisi-diri seseorang”. Karena itu dapat dikatakan bahwa metakognisi merupakan kesadaran tentang apa yang diketahui dan apa yang tidak diketahui. Metakognisi meliputi 3 (tiga) macam pengetahuan, yaitu: pengetahuan deklaratif, prosedural dan kondisional (Nurani, 2017: 35).

1. Pengetahuan deklaratif yaitu pengetahuan faktual yang diperlukan siswa sebelum menggunakan pikiran kritisnya.

2. Pengetahuan prosedural adalah pengetahuan mengenai cara melakukan prosedurprosedur belajar.

3. Pengetahuan kondisional adalah pengetahuan mengenai mengapa dan kapan melakukan pengetahuan deklaratif ataupun prosedural. 
Sedangkan, pengalaman metakognisi merupakan suatu pengalaman dan sikap berpikir yang terjadi sebelum, sesudah maupun selama adanya aktivitas berpikir. Pengalaman-pengalaman ini melibatkan strategi metakognisi yang digunakan untuk mengontrol aktivitas-aktivitas kognitif dan memastikan bahwa tujuan kognitif telah dicapai (Pratiwi, 2014). Aktivitas kognisi secara tipikal juga dipandang sebagai upaya untuk meregulasi atau menata kognisi yang mencakup perencanaan (planning) tentang cara menyelesaikan tugas, menyeleksi strategi kognitif yang akan digunakan, memonitor keefektifan strategi yang telah dipilih dan memodifikasi atau mengubah strategi yang digunakan ketika menemui masalah (Saputri, 2018: 48). Menurut Schraw dan Markman dalam (Mulyadi dkk., 2016: 216) terdapat 3 (tiga) macam keterampilan yang esensial dalam metakognisi, yaitu:

1. Perencanaan: banyaknya waktu yang disediakan untuk menyelesaikan tugas, pemilihan strategi yang digunakan, bagaimana memulai suatu tugas, sumber daya apa yang harus dilibatkan, instruksi mana yang harus diikuti, apa yang digunakan untuk menyelesaikan dan hal apa yang harus diberikan secara penuh (intens) dan lain sebagainya.

2. Monitor: kesadaran tentang "Mengapa saya melakukan?" Monitoring memerlukan pertanyaan “Apakah ini masuk akal?”, “Apakah saya mencoba melakukan terlalu cepat?”, “Apakah saya telah cukup belajar?”. Pemantauan melibatkan memeriksa kemajuan seseorang dan memilih strategi perbaikan yang tepat ketika strategi yang dipilih tidak bekerja.

3. Evaluasi: meliputi membuat penilaian (judgements) tentang proses dan hasil berpikir dan belajar. "Apakah saya akan mengubah strategi?”, “Apakah saya memerlukan bantuan?”, “Apakah tugas matematika sudah selesai saya kerjakan?”.

Berdasarkan hasil penelitian dan angket yang telah dibagikan kepada siswa kelas $\mathrm{X}$ MIPA SMA Negeri 3 Maros bahwa dari proses siswa menjawab hingga menemukan jawaban akhir diketahui bahwa masih ada siswa yang kesulitan mengetahui cara untuk mengingat pengetahuan, pengertian, konsep, dalam masalah yang telah mereka pelajari. Selain itu, siswa juga kurang mengetahui mengapa mereka menggunakan suatu prosedur, keterampilan atau strategi dalam pemecahan masalah. Padahal, mereka menjawab dengan benar tapi ketika diminta untuk menjelaskan proses menjawab, siswa hanya menjelaskan apa yang dikerjakan tanpa memeriksa kembali hasil yang didapat. Tidak hanya itu saja, dari hasil angket ditemukan juga bahwa ketika siswa dapat memecahkan suatu masalah, mereka mengetahui faktor-faktor penyebab kesulitannya dan mereka tidak berpikir 
mengenai langkah-langkah yang harus mereka lakukan itu adalah benar. Ini menunjukkan adanya keterampilan metakognisi siswa pada aspek pengalaman metakognisi saja. Namun pada aspek pengetahuan metakognisi, siswa kurang atau bahkan tidak mengetahui prosedur, konsep, strategi yang mereka gunakan.

Pada penelitian ini faktor kesulitan siswa dalam menyelesaikan soal matematika menjadi salah satu penyebab rendahnya pengaruh kemampuan metakognisi terhadap hasil belajar matematika. Hal tersebut dapat dilihat pada saat penelitian siswa hanya menjawab soal yang ia anggap mudah. Sehingga hanya sebagian nomor soal yang berhasil di selesaikan meskipun masih terdapat kekeliruan dalam penyelesaiannya. Selain itu, hambatan lainnya yang dihadapi dalam pembelajaran yaitu waktu yang tersedia relatif sedikit untuk melakukan pengembangan-pengembangan dalam pembelajaran. Sehingga, ketika guru meminta kepada siswa untuk mengecek apakah perencanaan yang dilakukan oleh siswa sudah tercapai atau belum dan bagaimana cara mengatasinya, hanya sebagian kecil saja yang bisa menjawab pertanyaan tersebut. Karena manajemen waktu dan kebiasaan siswa dalam mengatur pola pikirnya masih agak lamban. Seperti yang diungkapkan oleh Iskandar (2014) bahwa bagaimana siswa secara berangsur-angsur menguasai keterampilan metakognitif ini memerlukan suatu proses yang cukup lama.

Seperti yang diungkapkan Hartini (2017) bahwa setiap siswa yang telah memiliki kemampuan pemecahan masalah yang berkaitan dengan materi pembelajaran matematika akan sangat membantu proses pemahaman atau pembentukan pengetahuan baru bagi siswa. Dalam proses pemecahan masalah matematika tentunya ada langkah-langkah yang harus ditempuh untuk mendapatkan solusi dari persoalan yang ada (Lestari, Andinny \& Mailizar, 2019). Lebih lanjut lagi, kemampuan siswa untuk memecahkan masalah matematis perlu terus dilatih sehingga dia dapat memecahkan masalah yang dia hadapi (Effendi, 2012).

\section{KESIMPULAN}

Berdasarkan hasil penelitian dan analisis data yang telah dilakukan dapat disimpulkan bahwa kemampuan metakognisi yang mencakup pengetahuan metakognisi dan pengalaman metakognisi masing-masing berada pada kategori sedang dan tinggi. Selain itu, hasil hipotesis menunjukkan bahwa terdapat pengaruh yang signifikan kemampuan metakognisi dan hasil belajar matematika siswa dengan besarnya pengaruh $5,8 \%$. 
Berdasarkan hasil penelitian yang telah dikemukakan sebelumnya dan melihat kenyataan yang ada di lapangan maka peneliti mengemukakan beberapa saran diantaranya adalah:

1. Diharapkan menjadi masukan untuk siswa utamanya kepada tenaga pendidik dalam pembelajaran, selain memperhatikan kemampuan metakognisi juga tidak kalah pentingnya adalah memperhatikan faktor-faktor lain yang mempengaruh hasil belajar baik faktor internal maupun eksternal.

2. Sebaiknya guru dapat membantu siswa dalam mengelola kemampuan metakognisinya agar berdampak pada meningkatnya hasil belajar matematika siswa. Namun, siswa juga harus mengimbangi kemampuan metakognisinya dalam belajar dengan penerapan sesungguhnya dalam belajar matematika sehingga hasil belajar matematika yang diperoleh dapat meningkat.

3. Hasil penelitian ini dapat menjadi bahan informasi atau sumber referensi bagi peneliti maupun calon peneliti dalam melakukan penelitian selanjutnya yang berkaitan dengan variabel pada penulisan ini demi pengembangan hasil belajar matematika dimasa depan.

\section{DAFTAR PUSTAKA}

Arikunto, S. (2010). Penelitian Tindakan Kelas. Yogyakarta: Aditya Media.

Effendi, L. A. (2012). Pembelajaran Matematika Dengan Metode Penemuan Terbimbing Untuk Meningkatkan Kemampuan Representasi dan Pemecahan Masalah Matematis Siswa SMP. Jurnal Penelitian Pendidikan, 13(2), 1-10.

Fajriani, \& Nurdahniar. (2016). Pengaruh Metakognisi Terhadap Hasil Belajar Matematika Siswa Kelas X SMA Negeri Se Kabupaten Bulukumba. Jurnal Prosiding Nasional, 2(1), 285-290.

Hartini, S. (2017). Pengaruh Model Pembelajaran Quantum Teaching Pada Bentuk Penilaian Portofolio Berbasis Kelas dan Jenis Sekolah Terhadap Kemampuan Pemecahan Masalah Matematika Siswa. Mathline: Jurnal Matematika dan Pendidikan Matematika, 2(2), 119-132.

Hidayat, B. R., Sugiarto, B., \& Pramesti, G. (2013). Analisis Kesalahan Siswa Dalam Menyelesaikan Soal Pada Materi Ruang Dimensi Tiga Ditinjau Dari Gaya Kognitif Siswa (Penelitian Dilakukan Di SMA Negeri 7 Surakarta Kelas X Tahun Ajaran 2011/2012). Jurnal Pendidikan Matematika, 1, 39-46.

Iskandar. (2014). Pendekatan Keterampilan Metakognitif dalam Pembelajaran Sains di Kelas. Erudio, 2(2), 13 - 20.

Ismail, I., Sinilele, A., \& Rahmawati, R. (2019). Pengaruh Penerapan Model Pembelajaran Contekstual Teaching and Learning terhadap Pemahaman Konsep Matematika Peserta Didik Kelas VIII SMP Negeri 16 Mandai. Equals: Jurnal Ilmiah Ilmu Pendidikan Matematika, 2(2), 92-99.

Ismunandar, D., \& Nurafifah, L. (2018). Efektifitas Penggunaan Buku Ajar Berbantuan Geogebra untuk Mencapai Ketuntasan Hasil Belajar Matematis. Dialektika, 5(2), 7085. 
Kamid. (2013). Metakognisi Siswa dalam Menyelesaikan Soal Matematika. Jurnal Edumatica, 3(1), 64-72.

Lestari, I., Andinny,Y.\& Mailizar, M. (2019). Pengaruh Model Pembelajaran Situation Based Learning dan Kemandirian Belajar Terhadap Kemampuan Pemecahan Masalah Matematis. Jurnal JNPM (Jurnal Nasional Pendidikan Matematika), 3(1), 95-108.

Lusiana, R. (2017). Analisis Kesalahan Mahasiswa Dalam Memecahkan Masalah Pada Materi Himpunan Ditinjau Dari Gaya Kognitif. JPPM, 10, 24-29.

Mulyadi, S., Basuki, A. M. H., \& Raharjo, W. (2016). Psikologi Pendidikan dan Pendekatan Teori-Teori Baru dalam Psikologi. Jakarta: Parama Ilmu.

Nasrodin. (2018). Peningkatan Kemandirian dan Hasil Belajar Matematika Melalui Strategi Pembelajaran Tutor Sebaya Bagi Siswa SMK Muhammadiyah Delanggu Kelas XI PK Semester Gasal Tahun ajaran 2016/2017. Jurnal Konvergensi, 5(25), $69-78$.

Novitasari, N. (2015). Konstribusi Motivasi Terhadap Kemampuan Metakognitif Mahasiswa. Skripsi dipublikasikan. Universitas Pendidikan Indonesia: Bandung.

Nurani, M. (2017). Pengaruh Motivasi Belajar dan Kecemasan Matematika Terhadap Kesadaran Metakognisi dan Kaitannya dengan Hasil Belajar Matematika Siswa Kelas VIII di SMP Negeri 3 Sungguminasa pada Materi Bangun Ruang Sisi Datar. Skripsi dipublikasikan. Universitas Negeri Makassar, Makassar.

Nurmalasari, L. R., Winarso, W., \& Nurhayati, E. (2015). Pengaruh Kemampuan Metakognisi Terhadap Hasil Belajar Matematika di SMP Negeri 2 Leuwimunding Kabupaten Majalengka. Jurnal Nusantara Of Research, 2(2), 113-147.

Pratiwi, S.D. (2014). Profil Metakognisi Siswa SMP dalam Memecahkan Masalah Matematika Ditinjau dari Kemampuan Matematika Siswa. Mathedunesa, 3(2), 179 186.

Saputri, D. (2018). Pengaruh Pendekatan Scientific terhadap Kemampuan Metakognisi Peserta Didik pada Pembelajaran Agama Islam di SMAN 1 Barru. Skripsi dipublikasikan. Universitas Islam Negeri: Makassar.

Siswandi, E., Sujadi, I., \& Riyadi. (2016). Analisis Kesalahan Siswa Dalam Menyelesaikan Masalah Matematika Kontekstual Pada Materi Segiempat Berdasarkan Analisis Newman Ditinjau Dari Perbedaan Gender (Studi kasus pada siswa kelas VII SMPN 20 surakarta). Jurnal Elektronik Pembelajaran Matematika, 4, 633-643.

Suardi, Moh. (2018). Belajar \& Pembelajaran. Yogyakarta: Deepublish.

Sudjana, Nana. (2010). Proses dan Hasil Belajar. Jakarta: Bumi Aksara.

Syaiful. (2011). Metakognisi Siswa dalam Pembelajaran Matematika Realistik di Sekolah Menengah Pertama. Edumatica: Jurnal Pendidikan Matematika, 1(2), 1 - 13.

Syamsuriyawati, S., \& Setyawan, D. (2019). Efektivitas Pembelajaran Matematika Melalui Penerapan Model Pembelajaran Probing-Prompting pada Siswa Kelas VII. A SMP Hang Tuah Makassar. Equals: Jurnal Ilmiah Ilmu Pendidikan Matematika, 2(1), 1017.

Thayeb, T., \& Putri, A.P. (2017). Kemampuan Metakognisi untuk Meningkatkan Keterampilan Pemecahan Masalah Matematika Siswa Kelas VIII.B MTs Madani Alauddin Paopao Kabupaten Gowa. MaPan: Jurnal Matematika dan Pembelajaran, 5(1), $1-17$.

Wati, M. K., Sujadi, A. A., Studi, P., Matematika, P., Sarjanawiyata, U., Yogyakarta, T., \& Masalah, P. (2017). Analisis Kesalahan Dalam Menyelesaikan Masalah Matematika Dengan Menggunakan Langkah Polya Siswa Kelas VII SMP. Jurnal PRISMA Universitas Suryakencana, VI, 9-16. 
Widodo, S. A. (2013). Analisis Kesalahan Dalam Pemecahan Masalah Divergensi Tipe Membuktikan Pada Mahasiswa Matematika. Jurnal Pendidikan Pengajaran, 2, 106113. 
124 Pengaruh Kemampuan Metakognisi Terhadap Hasil Belajar Matematika Siswa SMA 